OPTIMIZATION OF VALUE MEASUREMENT METHODS

\title{
OPTIMIZATION OF VALUE MEASUREMENT METHODS
}

\author{
Kabir Bindawa Abdullahi \\ Umaru Musa Yar'adua University Katsina \\ Email: kabir.abdullahi@ umyu.edu.ng
}

\begin{abstract}
This paper addresses the issues of methodological problems and limitations regarding measuring values. A short scan review of values measurement methods from psychological and ethnobotanical approaches was made to enumerate some of those shortcomings. A new methodological approach, named Kab's Value Survey (KVS) was proposed and compared with other well adopted methods based on some important criteria to assess its suitability, uniqueness and novelty. The results of the comparisons shows that KVS for its considerations to the theoretical explanations distinguishes itself over other methods of value measurement in the sense that the methodological approach employed is more broad in scope and applications, simple, specific and reliable in terms of instruments for data collection, psychometric data analysis, and of course data presentation. The method however solved some of the criticized limitations that exist in other well adopted methods of values measurement from psychological and ethnobotanical perspectives.
\end{abstract}

Keywords: Values, Actions, Value-actions, Measurement, Methodology 
OPTIMIZATION OF VALUE MEASUREMENT METHODS

\section{Introduction}

When we think of our values, we reflect what actions, activities, attitudes and behaviors are important to us in our lives. Each of us holds and is influenced by numerous values with varying degrees of importance; the more important a value is to a person, the more likely he or she is to act in ways that promote the attainment of that value (Kluckhohn, 1951; Rokeach, 1973; Schwartz, 1992, 2006, 2012). Values are critical motivators of behaviors and attitudes which subsequently predicts actions (Schwartz, 2012; Parks-Leduc, 2015). Our attitudes are shaped and influenced behavioral intention, which in term shape actions (Fishbein and Ajzen, 1975). Over time, repeated habituations and engagement of value-actions is likely to strengthen values (Flouri, 1999; Sheldon, 2000; Goldberg, 2003; Hüther, 2006; Banerjee, 2008; Holmes, 2011). Values are abstract, desirable goals. Their importance is stable over time and across situations (Schwartz, 2012; Roccas, et al. 2017). Values are cognitive representations of basic motivations and are structured according to their compatibilities and conflicts (Schwartz 1992). Values are one important, especially central component of our self and personality, distinct from attitudes, beliefs, norms, and traits.

The growing body of literature on personal values has yielded both conceptual and methodological developments. Both are reflected in the growing number of instruments developed to measure personal values. The psychometric characteristics of any specific instrument have methodological implications (Roccas, et al. 2017). Although there are other methods long existed, but among the first theoretically developed and most used psychometric instruments for values measurement was the Schwartz Value Survey (Schwartz, 1992, 2006, 2012). The Schwartz Value Survey (SVS) reports value priorities of participants explicitly, by asking them to conduct a self-reference assessment based on points-scale. Recently, about 16 
OPTIMIZATION OF VALUE MEASUREMENT METHODS

different methods were compiled to measure value priorities. Each method differs from one another in the style of questions, number of items, response scale, and abstractness (Roccas, et al. 2017). The impacts among the instruments vary significantly, but all address the same problems of value priorities. SVS was reported to have been translated in 46 Languages worldwide (Rudnev, 2011). Despite the significance of these methods especially in psychological and sociological researches, they are however been challenged with some limitations (Hood, 2003; Lee, et al. 2005; Linderman and Verkasalo, 2005; Roccas, et al. 2017). Researchers have made enormous attempts to optimize these methods by addressing the limitations the previous instruments have, but up till now, the most recently developed psychometric methods such as short and broad Schwartz value Survey (SB SVS) of Sekerdej and Roccas (2016), Ten Item Value Inventory (TIVI) by Sandy et al. (2016), Twenty Item Value Inventory (TwIVI) by Sandy et al. (2016), and Animated Values Instrument (AVI) by Collins et al. (2017) have failed to address some of the limitations. The central focus of these interested researchers was to optimize the instrument of data collection for low number of questions, fewer items and simple instruction, comprehensive description and style of questioning (Roccas et al. 2017).

In another direction, the peoples' values for material object within an ethnos for the natural biodiversity constitute an important aspect of ethnobotany/ethno-medicine and ethnozoology. In particular, the scientific rigor of quantitative ethnobotany emerged by the development of relative cultural importance (RCI) indices that produce numerical scales or values that can provide data amenable to hypothesis testing, statistical validation, and comparative analysis (Hoffman and Gallaher, 2007; Mathur and Sundaramoorthy, 2013). In literature, there are about 30 different use-value methods that simply counts the number of different uses reported for each 
OPTIMIZATION OF VALUE MEASUREMENT METHODS

plant to assign importance of species in a community, degree of decline of use of popular plants, importance of a species for an informant, frequency citation and occurrence of plants, comparison of importance of plant groups, combined studies of cultural, practical and economic values to quantity the average number of informant know how for each species (Mathur and Sundaramoorthy, 2013). Despite the long use and application of use-value indexes, even among the most recently developed methods such as Use Value Index (UV) by Camou-Guerrero at al. (2008) and Quality Use Value (QUV) by Thomas et al. (2009) are however criticized with some limitations (Hoffman and Gallaher, 2007; Mathur and Sundaramoorthy, 2013).

Both the psychometric and ethnobotanical approaches, although psychometric methods are more theoretically based and advanced than ethnobotanical, ignored the most essential but covert aspect of values theories such as the issue of value-action gab, variety in methods of data collection and data analysis, shift from conventional ranking and rating approach to a more universal and more measurable approach of importance measurement, methodological broadness in scope and applications. Therefore, any future work is akin to the solution of these problems. Now, our solution is to rethink logically and reflect the theoretical explanations.

In this paper, I proposed a new optimized methodological approach that logically and theoretically takes account of these unsolved limitations. This paper is organized into sections, subsections and sub-subsections. The first section is an introduction. The second section is a short scan review of some commonly used methods for value measurement, their limitations and a theoretical reflection to address the existing limitations in the methods of values measurement. The third section presented the methodological items of the new proposed method of values measurement. The fourth section is a methodological and simulation comparison between the new proposed method and some other methods. The last, fifth section is the conclusion. 
OPTIMIZATION OF VALUE MEASUREMENT METHODS

\section{Literature Review}

This section is a short scan review of some commonly used methods of values measurement from psychological and ethnobotanical approaches and evaluated their limitations. The review also glanced at the methods and their limitations for correspondence with the theoretical and logical facts about values. I was able to sort and highlight some limitations common among most existing methods of value measurement and sought solutions from theoretical explanations.

\section{Psychological Approach of Value Measurement}

The research literature is rife with measures of values, attesting to the importance that the values construct has gained in the last decades. The instruments developed to measure basic values correspond to the definition of values as desirable goals that serve as guiding principles (Roccas, et al. 2017). A comprehensive report presented by Roccas, et al. (2017) in his report presented a comprehensive up-to-date list of 16 methods and instruments used for psychometric value measurement. He categorized them into panels based on the reference authors: Panel A was the seminal Rokeach Value Survey (RVS, Rokeach, 1973). Panel B was the lists of instruments developed by Schwartz over time. Panel C was the instruments developed by other researchers who draw on Schwartz's theory and are designed to measure the same value system. Finally, Panel D was the lists of measures that do not draw on Schwartz's model, but correspond to the same definition of values. Because of the space constraint, I shall not go to present the description of these methods individually, but all the methods address the following issues:

Data collection instrument. Questionnaire is a typically used method of data collection. Most questionnaires have the following feature: The methods measure the abstract or concrete nature of values. The number of items is determined by the number of values and its specific 
OPTIMIZATION OF VALUE MEASUREMENT METHODS

items considered. Depending on the method, it ranges from 10-105 items. Rating ranking and pairwise comparison approaches are employed to measure the respondents' judgment. In rating approach, value questionnaires asks participants to consider each item independently of how they view the other items, and rate its importance on an established scale points labeled as 7 (for supreme importance), 6 (for very important), 5, 4 (unlabeled), 3 (for important), 2, 1 (unlabeled), 0 (for not important), -1 (for opposed to my values). In ranking approach, respondents ask to compare the given items to each other and to hierarchically order them by importance relative to one another. In respondent is to compare between two items which one most important to him (Roccas, et al. 2017).

Instrument for data analysis. In psychometric analysis means of scores for each value items express the result of value priorities (Schwartz, 1992; Linderman and Verkasalo, 2005). Correlation method is the most used method of statistical analysis of the calculated results of values priorities. (Oishi, et al. 1998; Schwartz, et al. 2001; Linderman and Verkasalo, 2005).

\section{Limitations of psychometric instruments for personal value measurement}

Previous literatures emphasized their critics regarding the disadvantages the use of ranking scale, and may be the rating scale, the level of abstraction, the length and broadness of instruments and its questionnaire items, the response format and response scale, the crosscultural validation of the measurement instruments, the ordinality of the response scores and limit of data analysis, the difficulties of answering the questionnaire question (Hood 2003; Lee $e t$ al. 2005; Linderman and Verkasalo, 2005; Roccas, et al. 2017). However, the recent methodologies have addressed most of these limitations (Roccas, et al. 2017). I further added some the limitations that were not noticed and considered. These are: 
OPTIMIZATION OF VALUE MEASUREMENT METHODS

Response scale. Although rating scale is the most adopted almost all the methods. The assumption that equal gaps of importance between one attributes of importance to the other would ensure a fixed distribution for all respondents (Roccas, 2017). But understanding the strength and magnitude between each of the gabs may have relation with the age, experience, gender, socialization, and location etc of the individual respondent. However, the most important aspect of individual variations arrest at this point. Therefore, rating scale is insufficient at address this issue. Rating scale provide only abstract meaning about the abstract variations that from one rated point to the others.

Result's meaningfulness. The mean scores has sense in term of variation but psychologically or ethnoecologically not meaningful. The results are in some cases ambiguous. It is ambiguous in sense that the method may fail to provide consistent and valid result. For instance, if scale points 2, 1 and -1 are the only responded points in SVS method by 20, 50, and 90 respondents respectively, the mean score would be equal to zero, that means no values score at all, while it is invalid to accept.

Value-action gab. The methods did not consider and address the issue of value-actions gab, but only the instrumental state of values (abstract concept) is considered. The space that occurs when the values (personal and cultural) or attitudes of an individual do not correlate to his or her action is what the issue of value-action gab addressed. The theory of reasoned action states that behavioral intention is dependent on attitudes surrounding that behavior and social norms (Fishbein and Ajzen, 1975).

Individual or group variations. Although theories explained that values are stable cross culturally over time (Schwartz 2012; Roccas, et al. 2017), but individual or group differences in the choice or selection of values (which might change over time) is an important source 
OPTIMIZATION OF VALUE MEASUREMENT METHODS

statistical variation. It may be because of the inefficiency of the methods to provide value score per respondent prevented the evaluation of this difference.

Data collection methods. Questionnaire is the only method adopted for data collection. Thus cannot allow for experimentation and interview approaches. Mainly rating scale data is welcomed.

Reliability of the expected data. The data generated is less reliable, because the response of the respondents may be an imagination or representation of values.

Simplicity and time efficiency. Rating a question requires more time and reasoning as the response did not form a component of behavioral reflexes.

Methodological broadness in scope and applications. The value for material objects is neglected. For instance, values for our biodiversity, a specific objects. This limited the methodological applications in other field of studies such as ethnobotany and others.

\section{Ethnobotanical Approach of Value Measurement}

One of the first studies that compiled a good number of methods that were developed to measuring the importance of species was Hoffman and Gallaher (2007). He recorded 24 different methods. Recently, Mathur and Sundaramoorthy (2013) reported a more comprehensive up-todate list of ethnobotanical methods. His finding recorded about 30 different use value methods as being comprehended from literatures (Mathur and Sundaramoorthy, 2013). The major objectives associated with such types of studies carries importance of species in a community, degree of decline of use of popular plants, importance of a species for an informant, frequency citation and occurrence of plants, comparison of importance of plant groups, combined studies of cultural, practical and economic values to quantity the average number of informant know how for each species (Hoffman and Gallaher, 2007; Mathur and Sundaramoorthy, 2013). Space constraint 
OPTIMIZATION OF VALUE MEASUREMENT METHODS

will not allow presenting the description of these methods individually, but most of the methods address the following basic variables or parameters: Frequency of mentioned or use citations of a particular plant species, number of informants who cited a species important or useful, number of species, use categories, scaling (ranking and rating) of nominal or ordinal data of interest.

\section{Limitations of ethnobotanical methods of value measurement}

Hoffman and Gallaher (2007) and Mathur and Sundaramoorthy (2013) reported a good work that tries to enumerate some points of limitations that exist with the use of ethnobotanical indice. This two researchers independently reported that the methods failed to distinguish relative degree of importance for different use. Because the data are recorded per-respondent or informant, intra-cultural variability cannot be assessed. The methods are subjective, most are developed by a combine and split of other methods, ignore the dynamics of cultural importance, such as: distinctions between current and historical uses, frequency of use and relative degree of importance. Despite these critics, the methods still commonly used (Begossi, et al. 2002; Case, et al. 2005; Frei, et al. 1998; Voeks and Leony, 2004). In addition to what these two independent researchers have reported I then re-clarify and added the following observations as further limitations:

Methods of derivations. By clarifying what Hoffman and Gallaher (2007) have reported, the way some of the methods were developed or derived resulted to an increasing number of new methods. The researchers are cycling around some common variables. I viewed them in the following styles: 1) Modified-drive methods: In this case, a change or additions in of dependent or independent variables result to a new method. 2) Merged-drive methods: In this case, two or more methods are merged together with or without changing, addition or deletion in their dependent or independent variables to develop another new method. 3) Split-drive methods: In 
OPTIMIZATION OF VALUE MEASUREMENT METHODS

this case, one or more methods are split into unit variables which are either reorganized or modify their dependent or independent variables into a new method.

Consideration for other aspect of material values. Most of the methods emphasized on use-value of a natural plant biodiversity. In conceptual sense of ethnobotany, usage is not the only concern of ethnobotanist, but other aspects such as exploitation, consumption, marketing, processing value of natural plant biodiversity are interesting and important.

Result's meaningfulness. The calculated results are theoretically meaningless, but it only shows variations that exist. However, most of the methods cannot provide result per respondent. This represents another limitation that could prevent other forms of statistical analysis.

Result ambiguity. A species with the highest frequency of citations or use categories is considered most significant even if it is less frequently utilized over the others, or the use is historical not current. Therefore, frequency of use citations or use categories is conceived as an index of importance of that material value.

\section{Theoretical reflections for solution to the limitations of value measurement methods}

Literatures such as Fishbein and Ajzen (1975); Holmes (2011); Schwartz (2006, 2012); Parks-Leduc (2015) explained that our values are guiding forces that shapes and serve as a predictors of our actions (activities). Suppose that in a culturally dynamic population of individuals, a set of value-actions (activities) were allowed without restriction and limitation to be practiced. We can establish the following facts about these value-actions (activities):

Choice or selection of value-actions. Some individuals may chose to practice them (i.e recognize them valuably important or significant), while others may not practice. This freedom 
OPTIMIZATION OF VALUE MEASUREMENT METHODS

of self-direction forms among the basic features of human values (Schwartz, 2006, 2012; Holmes, 2012).

Degree of importance. The practitioners of such value-actions (activities) may practice with different degree (frequency) of importance or significance relative to others. This depends on their practical preferences for each value-action (activity). Studies and reports by Flouri (1999); Sheldon (2000); Goldberg (2003); Banerjee (2008) Hüther (2006); and Holmes (2011) reported that repeated habituations and engagement of value-actions is likely to strengthen values. The ordering of values by importance relative of others is recognized as one of the basic features of value priorities (Schwartz, 2006, 2012). Therefore, frequency of practice of particular value-actions (activity) relative to others indicates a relative degree of importance and strength of that particular valuable action (activity).

Preferences for value items and actions. The practitioners of such value-actions (activities) may choose to practice all, or select among others. This depends on their selective preferences for each valuable action (activity). The self-directional features of values direct our choice or selection of actions and events (Schwartz, 2006, 2012). Bilsky, Janik \& Schwartz, (2011); Davidov, et al., (2008); Schwartz, (2006) reported that existence of value across different cultural population and entities determine its universality. Therefore, frequency (number) of practiced items or categories is an important index of value diversity within the value domain or it distribution across different cultures or categories in consideration.

Population intensity and value dynamics. Over time, some among the practitioners may decline to practice, and some among the non-practitioners may accept to practice. Our values therefore not only change at different point of our lives, but also day-to-day (Holmes, 2011). Moreover, population changes (increase or decline) over time may likely to diminish or 
OPTIMIZATION OF VALUE MEASUREMENT METHODS

promote the intensity and representation of such value-actions within the population. Practitioners from different populations may have the same frequency of practice for a particular valuable activity, but the frequency of practitioners with respect to the population (practitioners' intensity) may significantly differ. Although studies by Bilsky, Janik \& Schwartz (2011); Davidov et al. (2008); Schwartz (2006) shows that values are cross-culturally the same, but variation exist between groups. The point address here is not the inter-cultural variations, but the intensity of value and its priority level in a population, which is expected to change with time and population growth. Therefore, frequency of practitioners for a particular value-actions and events in a population is an important factor that determines a population value practices.

In general sense, method of values measurement can therefore be expressed as the measure of the relative degree of importance or significance (express by frequency factor) attached to particular value-actions (activities) of an individual(s) in a given population over a period of time. And its distribution in different categories determines its universality. From these facts, important parameters and variables were extracted which will be discussed in the subsequent section.

\section{New proposed Methodology:}

\section{Kab's Value Survey}

This new proposed method, named Kab's Value survey (KVS), discussed the problems of data collection instruments, data analysis, result interpretation and result presentation.

\section{Instruments for data collection}

This proposed methodology demonstrated three approaches for data collection. Depending on the time and need for the research design, a rapid appraisal approach of data collection can be used by taking lower categories of habituations. For instance, only daylightly or 
OPTIMIZATION OF VALUE MEASUREMENT METHODS

daynightly and weekly practiced actions of the respondents can be chosen. See table 1 and 2. In this method, three approaches of data collection are proposed. These are:

Questionnaire Approach. In this questionnaire (sample example is presented in table 1 and 2), the respondent(s) will be ask to select a frequency factor (a factor of habituation) that he/she has been engaging himself/herself in a particular set value-actions (activities) that justify the significance he/she gives to a particular value type in question. In narrower cases, other field of studies such as ethnobiology may be interested for the material value (worthiness) of a particular object(s). In this approach, the action-state of a specific value types are considered as a predictors and confirmers of values. This style of questioning has a lot of advantages over the rating or ranking the respondents' judgments about the abstract nature of value: First advantage, value-action gab is considered and bridged, because the action-state of values is considered and measured. Secondly, data is more reliable because the question asks the actual behavioral actions (practice) of the respondents not an imagination or representation of values. Thirdly, response to the questions requires less time, because the respondent(s) might have developed some behavioral reflex about the questions. 
OPTIMIZATION OF VALUE MEASUREMENT METHODS

Table 1: Sample of questionnaire for some expected specific actions related to a value type

\begin{tabular}{|c|c|c|c|c|c|c|c|}
\hline \multicolumn{3}{|c|}{ Respond only to value types that relates to you as a GUIDING PRINCIPLE in your LIFE } & \multicolumn{5}{|c|}{ Tick only ONE appropriate to your choice } \\
\hline Statement of impression & Value type & Behavioral actions & Year & Day & Week & $\begin{array}{l}\text { Daylight OR } \\
\text { Day-night }\end{array}$ & Day and night \\
\hline \multirow[t]{6}{*}{ Because of the value I have for my } & \multirow[t]{6}{*}{ Health } & \multirow{6}{*}{$\begin{array}{l}\text { I go for routine medical check-up every ..... } \\
\text { I take regular exercise every ...... } \\
\text { I observe proper hygiene every ..... } \\
\text { I do regular sanitation every ...... } \\
\text { I abstain from drug abuse every ..... } \\
\text { I avoid harmful products every ...... }\end{array}$} & & & & & \\
\hline & & & & & & & \\
\hline & & & & & & & \\
\hline & & & & & & & \\
\hline & & & & & & & \\
\hline & & & & & & & \\
\hline \multirow[t]{3}{*}{ Because of the value I have for the } & \multirow[t]{3}{*}{ Biodiversity } & \multirow{3}{*}{$\begin{array}{l}\text { I care for the biodiversity every ...... } \\
\text { I conserve* it every ...... } \\
\text { I manage** it every ..... }\end{array}$} & & & & & \\
\hline & & & & & & & \\
\hline & & & & & & & \\
\hline \multirow[t]{3}{*}{ Because of the value I have for the } & \multirow[t]{3}{*}{ Security } & \multirow{3}{*}{$\begin{array}{l}\text { I employ/adopt guards every ...... } \\
\text { I become vigilant every ...... } \\
\text { I share intelligence every ..... }\end{array}$} & & & & & \\
\hline & & & & & & & \\
\hline & & & & & & & \\
\hline \multirow[t]{3}{*}{ Because of the value I have for the } & \multirow[t]{3}{*}{ Morality } & \multirow{3}{*}{$\begin{array}{l}\text { I act with morality ..... } \\
\text { I promote it every ..... } \\
\text { I enforce it every ...... }\end{array}$} & & & & & \\
\hline & & & & & & & \\
\hline & & & & & & & \\
\hline
\end{tabular}

*Conserving it signifies that I do not exploit any threatened species.

*Managing it signifies that I regenerate it, wisely exploit it while avoid illegal cutting and pouching of plants and animals respectively. 
OPTIMIZATION OF VALUE MEASUREMENT METHODS

Table 2: Sample of questionnaire for values for a specific material object.

\begin{tabular}{|c|c|c|c|c|c|c|c|c|c|c|}
\hline \multicolumn{3}{|c|}{ Respond only to statements that relate to you } & \multicolumn{8}{|c|}{ Tick only ONE appropriate to your choice } \\
\hline Statement of impression & Value type & Behavioral actions & Year & Day & Week & $\begin{array}{l}\text { Daylight OR } \\
\text { Day-night }\end{array}$ & $\begin{array}{l}\text { Daylight \& } \\
\text { Day-night }\end{array}$ & $\begin{array}{l}1-2 \\
\text { times }\end{array}$ & $\begin{array}{l}2-3 \\
\text { times }\end{array}$ & $\begin{array}{l}3-4 \\
\text { times }\end{array}$ \\
\hline \multirow{5}{*}{$\begin{array}{l}\text { Because of the medicinal } \\
\text { importance and significance of }\end{array}$} & \multirow{5}{*}{$\begin{array}{l}\text { Balanite plant, } \\
\text { I use/give its parts } \\
\text { for management of }\end{array}$} & \multirow{5}{*}{$\begin{array}{l}\text { Pile every ..... } \\
\text { Malaria every ..... } \\
\text { Measles every ...... } \\
\text { Typhoid every ..... } \\
\text { Infections every ...... }\end{array}$} & & & & & & & & \\
\hline & & & & & & & & & & \\
\hline & & & & & & & & & & \\
\hline & & & & & & & & & & \\
\hline & & & & & & & & & & \\
\hline \multirow{3}{*}{$\begin{array}{l}\text { Because of the nutritional } \\
\text { importance of }\end{array}$} & \multirow{3}{*}{$\begin{array}{l}\text { Maringa, } \\
\text { I use it as food in }\end{array}$} & \multirow{3}{*}{$\begin{array}{l}\text { Soups every ...... } \\
\text { Drinks every ..... } \\
\text { Snacks every ..... }\end{array}$} & & & & & & & & \\
\hline & & & & & & & & & & \\
\hline & & & & & & & & & & \\
\hline \multirow{3}{*}{$\begin{array}{l}\text { Because of the market } \\
\text { values of }\end{array}$} & \multirow[t]{3}{*}{ Mobile phones, we } & Produce them every ...... & & & & & & & & \\
\hline & & Wholesale them every ... & & & & & & & & \\
\hline & & Retail them every ..... & & & & & & & & \\
\hline \multirow{3}{*}{$\begin{array}{l}\text { Because of the economic } \\
\text { importance of }\end{array}$} & \multirow[t]{3}{*}{ Woody trees, I } & Exploits them every ...... & & & & & & & & \\
\hline & & Process them every ...... & & & & & & & & \\
\hline & & Sale them every ...... & & & & & & & & \\
\hline
\end{tabular}


OPTIMIZATION OF VALUE MEASUREMENT METHODS

Experimental Approach. In this approach, the concepts are the same as other approaches here explained. The only difference is that, it employs a visual observations and recordings the behavioral actions (activities) of every of individuals in the study area or subjects. This design could be time intensive and visually critical. The data in this case is very reliable because live actions about values are recorded. Depending on the time and need for the research design, a rapid appraisal approach of experimentation can be used by taking lower categories of habituations. For instance choosing only daylightly or daynightly and weekly observations.

Interview Approach. This approach is also similar in concepts to the other approaches here explained. Only that in this case, verbal and may be face-to-face oral interview could be made with the potential respondent(s). The related conservation would asks the respondent(s) to list and for each listed items to state the frequency, for the actions or activities he/she engaged himself/herself for the significance he/she give to a particular value types in question.

\section{Important variables or parameters}

Note that, in all these approaches for data collection, the ethical requirements must be fulfilled. Furthermore, each approach should consider the following variable or parameters:

Actions (Activities). Actions are the action-state driven by our values. Each value transcends specific action, but it is recognized by sets of specific value-actions (activities) (Schwartz, 2006, 2012; Holmes, 2011). Table 3 below presented some examples of a specific value and its possible or expected sets of value-actions (activities). 
OPTIMIZATION OF VALUE MEASUREMENT METHODS

Table 3: Some examples of value types and their possible behavioral actions

\begin{tabular}{|c|c|}
\hline Value type & Behavioral actions \\
\hline Health & $\begin{array}{l}\text { Routine medical check-up, dietary control, exercise regularly, proper } \\
\text { hygiene, regular sanitations, drugs administrations, routine vaccination, avoid } \\
\text { consuming harmful products, abstain from drug abuse every etc. }\end{array}$ \\
\hline Security & Employ guards, become sensitive and vigilant, share intelligence, etc. \\
\hline Nutrition & Routine meal, crop cultivation, animal rearing, etc. \\
\hline $\begin{array}{l}\text { Social and } \\
\text { political power }\end{array}$ & Accept leadership and responsibilities, etc \\
\hline Family & Marriage, child bearing, etc. \\
\hline Biodiversity & $\begin{array}{l}\text { Biodiversity conservation (routine management and regeneration), } \\
\text { biodiversity utilization (usage, exploitation, processing), etc. }\end{array}$ \\
\hline Education & $\begin{array}{l}\text { Attend schools, habitual reading, perform assignments, attend lectures and } \\
\text { practical, conduct research, etc. }\end{array}$ \\
\hline Tradition & Celebrates festivals, new year, ceremonies, etc. \\
\hline Achievement & Strive harder, cares for others, etc. \\
\hline Personalities & Behave modest, dress decent, keep promise and appointments, etc. \\
\hline Wealth & Business commitments, entrepreneurship, involvement in workplace, etc. \\
\hline Autonomy & Strive for political and social independence and freedom, etc. \\
\hline Politics & Contests for an elections, voters an elections, Campaign for an election, etc. \\
\hline Religion & $\begin{array}{l}\text { Pray regularly, attend prayer meetings, propagates the religion and its } \\
\text { teachings, etc. }\end{array}$ \\
\hline Morality & $\begin{array}{l}\text { Establish an ethical standards, promote an ethical standard, enforce an ethical } \\
\text { standards, etc. }\end{array}$ \\
\hline Socialization & $\begin{array}{l}\text { Educates our child, accept and utilize technological innovation, interacts with } \\
\text { people, etc. }\end{array}$ \\
\hline Technology & Design and develop infrastructure, creates new ideas and innovations, etc \\
\hline Language & Speak it, teach it, develop it and etc. \\
\hline
\end{tabular}


OPTIMIZATION OF VALUE MEASUREMENT METHODS

From table 3, we can understand that by attaching an importance to a specific value type initiates the development of an attitudes and behaviors that stimulates the onsets of several behavioral actions (activities). For instance, recognizing the significance of our health stimulates us for routine medical check-up, dietary control, exercise regularly, hygiene, sanitations, drugs administrations, avoid consuming harmful products, abstain from drug abuse every and etc. The average score of each value action express the absolute value score.

Frequency of action (activity). Frequency by a certain factor, of individual's practice or action for a particular value items in question is to be questioned, recorded or ask in the course of questionnaire, experimentation, or interview respectively. Frequency of actions can be recorded by a symmetric or asymmetric factor. To establish an event's frequency factor that is universal, simple to the understanding of common people, three approaches can be considered. For consistent reference and result comparisons, one style of event's factor should be chosen and adopted.

Calendar Approach: This approach employs the use of calendar attributes (events), specifically the repeated habituation of value-action every year, month, week, daylight, daynight, day and night. This attributes of calendar are considered as the main event's frequency factors The approach of using this events remain fix and serve as a reference guide or point upon which all other event's frequency factors are linked and composed. By logical sense, we assume that any value-action that is habitually repeated every day and night reserve the highest degree of importance upon which other events' frequency factors are related. The least relative order of importance is the yearly habituation of value-actions. Table 4 presented some examples.

Clock Approach: In this case, factor by clock events are used. It can be symmetric or asymmetric in factor. In choosing this approach, one should note that with the exception of 
OPTIMIZATION OF VALUE MEASUREMENT METHODS

biological actions, almost all forms of human action (activities) are rarely repeated continuously on every clock time bases. Table 5 presented some examples.

Researcher-design Approach: This approach constitutes other validated and liable event factor that the researcher designed that corresponds to the need of the research design.

Table 4: Calendar Approach of event's frequency factor design

\begin{tabular}{|c|c|c|c|c|}
\hline $\begin{array}{l}\text { Sign of habituation } \\
\text { or repetition }\end{array}$ & $\begin{array}{l}\text { Descriptors/Event's } \\
\text { Frequency Factor }\end{array}$ & $\begin{array}{c}\text { Scaling and } \\
\text { RERN }\end{array}$ & $\begin{array}{l}\text { Rank identity } \\
(E R N)_{n}\end{array}$ & Remarks \\
\hline \multirow[t]{5}{*}{ Every } & Year & 1 & $(E R N)_{1}$ & \multirow{5}{*}{$\begin{array}{l}\text { Asymmetric mono-factor, } \\
\text { Symmetric scale and main } \\
\text { or reference frequency factor }\end{array}$} \\
\hline & Month & 2 & $(E R N)_{2}$ & \\
\hline & Week & 3 & $(E R N)_{3}$ & \\
\hline & Daylight or Day-night & 4 & $(E R N)_{4}$ & \\
\hline & Day and night & 5 & $(E R N)_{5}$ & \\
\hline \multirow[t]{5}{*}{ Every } & 5 days and nights & 4.1 & $(E R N)_{5}$ & \multirow{5}{*}{$\begin{array}{l}\text { Symmetric di-factors, } \\
\text { and Asymmetric di-scales }\end{array}$} \\
\hline & 4 days and nights & 4.3 & $(E R N)_{5}$ & \\
\hline & 3 days and nights & 4.5 & $(E R N)_{5}$ & \\
\hline & 2 days and nights & 4.7 & $(E R N)_{5}$ & \\
\hline & 1 days and nights & 4.9 & $(E R N)_{5}$ & \\
\hline \multirow[t]{3}{*}{ Every } & 6 weeks & 2.3 & $(E R N)_{3}$ & \multirow{3}{*}{$\begin{array}{l}\text { Symmetric di-factors } \\
\text { and Symmetric scales }\end{array}$} \\
\hline & 4 weeks & 2.6 & $(E R N)_{3}$ & \\
\hline & 2 weeks & 2.9 & $(E R N)_{3}$ & \\
\hline \multirow[t]{5}{*}{ Every } & 5 daylights, 0-3 times & 3.11 & $(E R N)_{4}$ & \multirow{5}{*}{$\begin{array}{l}\text { Symmetric tri-factors } \\
\text { and Asymmetric scales }\end{array}$} \\
\hline & 4 daylights, 4-6 times & 3.33 & $(E R N)_{4}$ & \\
\hline & 3 daylights, 7-9 times & 3.55 & $(E R N)_{4}$ & \\
\hline & 2 daylights, $10-12$ times & 3.77 & $(E R N)_{4}$ & \\
\hline & 1 daylights, $13-15$ times & 3.99 & $(E R N)_{4}$ & \\
\hline
\end{tabular}

RERN = Resultant event's rank number. 
OPTIMIZATION OF VALUE MEASUREMENT METHODS

Table 5: Clock Approach of event's frequency factor design

\begin{tabular}{|c|c|c|c|c|}
\hline $\begin{array}{l}\text { Sign of } \\
\text { habituation } \\
\text { or repetition }\end{array}$ & $\begin{array}{l}\text { Descriptors/Event's } \\
\text { Frequency Factor }\end{array}$ & $\begin{array}{l}\text { Scaling and } \\
\text { RERN }\end{array}$ & $\begin{array}{l}\text { Rank identity } \\
(E R N)_{n}\end{array}$ & Remarks \\
\hline \multirow[t]{3}{*}{ Every } & Hour & 4.3 & $(E R N)_{5}$ & \multirow{3}{*}{$\begin{array}{l}\text { Asymmetric mono- } \\
\text { factor } \\
\text { and Symmetric scale }\end{array}$} \\
\hline & Minute & 4.6 & $(E R N)_{5}$ & \\
\hline & Second & 4.9 & $(E R N)_{5}$ & \\
\hline \multirow[t]{5}{*}{ Every } & 21 hours & 4.31 & $(E R N)_{5}$ & \multirow{5}{*}{$\begin{array}{l}\text { Symmetric di-factors } \\
\text { and Asymmetric } \\
\text { scales }\end{array}$} \\
\hline & 16 hours & 4.33 & $(E R N)_{5}$ & \\
\hline & 11 hours & 4.35 & $(E R N)_{5}$ & \\
\hline & 6 hours & 4.37 & $(E R N)_{5}$ & \\
\hline & 1 hours & 4.39 & $(E R N)_{5}$ & \\
\hline \multirow[t]{3}{*}{ Every } & 9 minutes, $21-30$ times & 4.639 & $(E R N)_{5}$ & \multirow{3}{*}{$\begin{array}{l}\text { Symmetric tri- } \\
\text { factors } \\
\text { and Symmetric } \\
\text { scales }\end{array}$} \\
\hline & 6 minutes, $11-20$ times & 4.666 & $(E R N)_{5}$ & \\
\hline & 2 minutes, $0-10$ times & 4.693 & $(E R N)_{5}$ & \\
\hline
\end{tabular}

RERN = Resultant event's rank number.

Established categories or parameters or strata. The issue of values universality necessitates for the consideration of an established categories or parameters. Universality is in sense that how uniform values are across different cultures, ethnicities, ages, social status, etc. These variables are denoted by ' $N C$ ' letters.

Activists. Activists refer the active respondents or informants of a target population who are engaged in a particular activity. Population activists, (denoted by $\mathrm{Na}$ letters) refer to the sum of the active events activists for a particular value action in a given population (See equation 1). Events activists (denoted by na letters) refers to a member of a population activists who are involved in an action (activity) at a given event of a particular value item. (See equation 1).

$$
N a=\sum(\mathrm{na})
$$


OPTIMIZATION OF VALUE MEASUREMENT METHODS

Where:

$N a$ : total number of population activists

na: total number of particular event activists

\section{Methods of Data Analysis}

In this subsection of the paper, emphasis is on development of primary approach (psychological or ethnoecological analysis) that integrates and associates the generated data into a theoretically meaningful value. In addition to that, a possibility of further secondary analysis (statistical analysis) of the primary results is highlighted.

Psychological or ethnoecological analysis. It is rarely difficult to find any statistical tool that can summarize all these bulk of discrete or continues data at a time into a meaningful conclusion. Therefore, psychological or ethnoecological analysis are important basic and primary approach for simplifying the logical data and variable into a psychological or ethnoecologically meaningful result. Any primary approach must satisfy the requirements of the data types and theoretical considerations for a valid and reliable result.

Pre-analysis of psychometric data. This involve sorting and organizing the disorganized data into logical variables and relationship

Organization and scaling of data. The generated data from the respondents (whether an interval, ratio, ordinal, or nominal data), which has been organized by factor of event's frequency(ies), need to be scaled in a proper order. Ranking or rating scale can be used, but each has its own characteristic advantages and limitations. It should be noted that data ranking or rating is quite different from that of rating or ranking a questions of a questionnaire. Data rating or ranking in this case usually produce the same magnitude if same order and features/command are used. 
OPTIMIZATION OF VALUE MEASUREMENT METHODS

The systematic order of scaling (ranking) in ascending manner must begin from the event (the description of factor) with the least (lowest) frequency to the maximum (highest) frequency. The numerical value assigned to each event is called event's rank number $(E R N)$, which is express by equation 2. Depending on the number of items or groups established, a symmetrical or asymmetrical scale is produced for odd or even number of items or categories respectively.

\section{Other variables that may be considered}

Resultant Event's Rank Number: In an incidence where the researcher considered more than one event's frequency factors at a time, the resultant event's rank number $(E R N)$ of the multiple scales is the sum of fractional ranks of event's factor (FREF) subtracted by 1. FREF are sub-factors within the reference (calendar) event's frequency factor that are organized in a series of respective fractions. The number of digits of resultant ERN tells the number of event's frequency factors composed. Table 4 and 5 presented some examples.

$$
(R E R N)_{n}=\left(\frac{F E R N}{1}+\frac{S E R N}{10}+\frac{T E R N}{100}+\ldots \ldots \ldots \frac{x E R N}{10^{y}}\right)-1
$$

Where:

$y=$ a count of series from zero $(y=0,1,2, \ldots \ldots)$

$R E R N=$ Resultant event's rank number

$E R N=$ Event's rank number

$F E R N=$ Event's rank number of first (the main and reference) order event's frequency

$S E R N=$ Event's rank number of second order event's frequency

$T E R N=$ Event's rank number of third order event's frequency

$x E R N=$ Event's rank number of last order event's frequency

Note that, the scaling for $x E R N$ within the sub-categories of any specific order of event's frequency except for the first order must be within a range greater than zero (0) and equals to 
OPTIMIZATION OF VALUE MEASUREMENT METHODS

nine (9). For example, these symmetric ranges can be adopted, depending on the number of subcategories wish to consider: $(1,2,3,4,5,6,7,8,9) ;(1,3,5,7,9) ;(3,6,9) ;(2,4,6,8)$; or $(4,8)$. It should be however also note that the scale of the first order event's frequency is always fixed for any research design in which 1,2,3,4, and 5 must be always assign to any event that occurs every year, every month, every week, every daylight or every day-night, and every day and night respectively.

Frequency of Population Activists: Frequency of Population Activist (denoted by FPA letters) refers to the fraction of active population activists number $(\mathrm{Na})$ to the total number of population samples $(\mathrm{Np})$. Frequency of population activists is express by equation (3).

$$
\mathrm{FPA}=\frac{\mathrm{Na}}{\mathrm{Np}}
$$

Where:

$N a$ : total number of population activists

$N p$ : total number of population sample

Relative Frequency of Event Activists: Relative Frequency of Event Activists (denoted by RFEA letters) refers to the fraction of a particular event activists number ( $n a$ ) relative to the total number of all other events' activists $(\mathrm{Na}$ ) inclusive. Relative frequency of event activists is express by equation (4).

$$
\mathrm{RFEA}=\frac{\mathrm{na}}{\mathrm{Na}}
$$

Where:

na: total number of particular event activists

$\mathrm{Na}$ : total number of population activists 
OPTIMIZATION OF VALUE MEASUREMENT METHODS

Formula for calculating Value priority Score. Two formulae were developed for psychometric data analysis for individual or population value priorities and value universality. These are

Action-value index or Activity-value index (AVI): In section 3, the method of values measurement is seen as the measure of the relative degree of importance or significance (by frequency factor) attached to particular value-actions (activities) of an individual(s) in a given population over a period of time. In this logical and theoretically driven definition, we have these important variables: (1) frequency of value-actions (activities), which is organized and scale ranked as $E R N$, as previously explained, (2) relative frequency of event's activists, (3) population intensity of activists (equivalent to frequency of population activists). The logical interaction of the variable is given by equation 5 . The average mean scores of value items is regarded as average value-action index, AAVI. Both the AVI and AAVI express value priority.

Per single respondent:

$$
\mathrm{AVI}=\frac{(\mathrm{RERN})_{\mathrm{n}}}{5}
$$

Per population:

$$
\begin{aligned}
& \mathrm{AVI}=\left\{\begin{array}{c}
\left(\frac{(\mathrm{RERN})_{1}}{5} \times \frac{\mathrm{na}_{1}}{\mathrm{Na}}\right)+\left(\frac{(\mathrm{RERN})_{2}}{5} \times \frac{\mathrm{na}_{2}}{\mathrm{Na}}\right)+\left(\frac{(\mathrm{RERN})_{3}}{5} \times \frac{\mathrm{na}_{3}}{\mathrm{Na}}\right)+ \\
\left(\frac{(\mathrm{RERN})_{4}}{5} \times \frac{\mathrm{na}_{4}}{\mathrm{Na}}\right)+\left(\frac{(\mathrm{RERN})_{5}}{5} \times \frac{\mathrm{na}_{5}}{\mathrm{Na}}\right)
\end{array}\right\} \times \frac{\mathrm{Na}}{\mathrm{Np}} \ldots \ldots \ldots(5.2) \\
& \mathrm{AVI}=\left\{\left(\begin{array}{c}
(\mathrm{RERN} \times \mathrm{na})_{1}+(\mathrm{RERN} \times \mathrm{na})_{2}+(\mathrm{RERN} \times \mathrm{na})_{3}+ \\
(\mathrm{RERN} \times \mathrm{na})_{4}+(\mathrm{RERN} \times \mathrm{na})_{5}
\end{array}\right)\right\} \times \frac{\mathrm{Na}}{\mathrm{Np}} \ldots \ldots \ldots(5.3) \\
& \mathrm{AVI}=\frac{(\mathrm{RERN} \times \mathrm{na})_{1}+(\mathrm{RERN} \times \mathrm{na})_{2}+(\mathrm{RERN} \times \mathrm{na})_{3}+(\mathrm{RERN} \times \mathrm{na})_{4}+(\mathrm{RERN} \times \mathrm{na})_{5}}{5 \times \mathrm{Np}}
\end{aligned}
$$


OPTIMIZATION OF VALUE MEASUREMENT METHODS

$$
\begin{array}{r}
\mathrm{AVI}=\sum_{\mathrm{n}=1}^{5}\left(\frac{(\text { RERN } \times \mathrm{na})_{\mathrm{n}}}{5 \times \mathrm{Np}}\right) \ldots \ldots \\
\mathrm{AVI}=\frac{1}{5 \times \mathrm{Np}} \times \sum_{\mathrm{n}=1}^{5}(\text { RERN } \times \mathrm{na})_{\mathrm{n}}
\end{array}
$$

Per individual and per population:

$$
\mathrm{AAVI}=\sum_{\mathrm{n}=1}^{\infty}(\mathrm{AVI})_{\mathrm{n}} \times \frac{1}{\mathrm{nvi}} .
$$

Where:

$n v i=$ Number of value items

$R E R N=$ Resultant event's rank number

$n a=$ Total number of event activists

$N a$ : Total number of population activists

$N p$ : Total number of population sample

$5=$ is the maximum event's rank number (ie. of every day and night frequency of valueactions

Action-value diversity index or Activity-value diversity index (AVDI): Action-value diversity index (AVDI) refers to the measure of the universality of values as its existence in different aspect of established categories. It can be express by the equation 6 .

$$
\operatorname{AVDI}=\sum_{\mathrm{n}=1}^{\infty}(\mathrm{AAVI})_{\mathrm{n}} \times \frac{1}{\mathrm{NC}}
$$

Where:

$N C=$ number of established categories

Statistical analysis: The results obtained from the psychometric analysis can be statistically analyzed for the existing variation within individuals in a population (in such case per respondent value score is require), or between the comparing categories, or groups or 
OPTIMIZATION OF VALUE MEASUREMENT METHODS

entities. These outcomes serve as a benchmark upon which all generalizations can be made about the subject in question (values). There are diverse statistical models for data analysis, but the choice depending on what purpose is the analysis, data type, variables, and others.

Result interpretation. Interpretation of the result enables the researcher to make either psychologically or ethnobiologically or statistically meaningful conclusions, justification and recommendations. For making a generalization in sciences, any approach is insufficient except drawn from statistical results. I attempted here to provide symmetric ranges for the primarily analyzed result of action-value index and action-value diversity index for drawing a simple conclusion about values. See table 6.

Table 6: Result ranges and interpretations

\begin{tabular}{lll}
\hline Value Ranges & $\begin{array}{l}\text { Action-value Index } \\
\text { (AVI/AVP) }\end{array}$ & $\begin{array}{l}\text { Action-value Diversity } \\
\text { Index (AVDI/ADVP) }\end{array}$ \\
\hline 0 & No & No \\
$>0-0.20$ & Low & Low \\
$0.21-0.40$ & Moderate & Moderate \\
$0.41-0.60$ & High & High \\
$0.61-0.80$ & Extreme & Extreme \\
$0.81-1.00$ & Extraordinary & Extraordinary \\
\hline
\end{tabular}

Result presentation. The results of primary and secondary analysis can be presented by any possible methods tabular, graphic and others. But it is important to note that, best presentation of result appeals visually and logically the existing variations among parameters.

\section{Comparisons and Discussions}

The new proposed method is compared with other methods methodologically and by simulation comparison. 
OPTIMIZATION OF VALUE MEASUREMENT METHODS

\section{Methodological comparisons}

In this subsection, the new proposal of this article was compared with other methods from psychological and ethnobotanical approaches based on some important criteria.

Table 7 and 8 presented comparisons between KVS and a well known most used method of values measurement in psychology (SVS method) and also with about 30 well adopted methods of value measurement in ethnobotany. The criteria for the comparisons made consideration to some parameters that reflects the theoretical discussions about values. The result of comparison shows that KVS method has some distinguishing advantages over SVS and all the ethnobotanical methods in terms of simplicity (for the questions, for the scale descriptors, for the understanding of common people), selectivity (to a variety of data collection instruments, to the responses), specificity (to which dimension is the result, to which respondent, to which value-action is practice), broadness (in scope and applications) of the measurement instruments for data collection, primary data analysis, and of course data presentation. The approach employed in KVS method made a reasonable consideration to the theoretical explanations about values to address the criticized limitations that exist in all the well known and adopted methods of values measurement such as SVS and others. 
OPTIMIZATION OF VALUE MEASUREMENT METHODS

Table 7: Comparisons between KVS and SVS methods

\begin{tabular}{|c|c|c|}
\hline Criteria & KVS Method & SVS Method \\
\hline $\begin{array}{l}\text { Scale of } \\
\text { measurement }\end{array}$ & $\begin{array}{l}\text { Frequency ranking scale (by event's factor) is } \\
\text { used for the questions. }\end{array}$ & $\begin{array}{l}\text { Non-frequency rating scale is used for the } \\
\text { questions. }\end{array}$ \\
\hline \multirow[t]{5}{*}{$\begin{array}{l}\text { Scale descriptors/ } \\
\text { Response scale }\end{array}$} & $\begin{array}{l}\text { Universal, simple to understand and recall by the } \\
\text { respondents. }\end{array}$ & $\begin{array}{l}\text { Not universal, difficult to understand and recall by } \\
\text { the respondents. }\end{array}$ \\
\hline & Allow for uniform response without bias. & $\begin{array}{l}\text { Response is influenced by age, sex, education, } \\
\text { experience and social status. }\end{array}$ \\
\hline & $\begin{array}{l}\text { Have frequency factor. And more than one can be } \\
\text { and considered at a time (multiple factors) }\end{array}$ & Have no frequency factor. \\
\hline & $\begin{array}{l}\text { Relative frequency actions provide actual } \\
\text { meaning about the variations that exist from one } \\
\text { frequency factor to the others. }\end{array}$ & $\begin{array}{l}\text { Rating scale provide abstract meaning about the } \\
\text { variations that exist from one rated scale point to } \\
\text { the others. }\end{array}$ \\
\hline & $\begin{array}{l}\text { Are measurable, but their measurement is an } \\
\text { approximation of what is habitually repeated. }\end{array}$ & Are not measurable. \\
\hline Result & $\begin{array}{l}\text { The mean scores has sense in term of variation } \\
\text { and as well psychologically or ethnoecologically } \\
\text { meaningful. It is also probabilistic in range. } \\
\text { Is never ambiguous. }\end{array}$ & $\begin{array}{l}\text { The mean scores has sense in term of variation but } \\
\text { psychologically or ethnoecologically not } \\
\text { meaningful. It is not probabilistic in range. } \\
\text { Is in some cases ambiguous*. }\end{array}$ \\
\hline $\begin{array}{l}\text { Respondent } \\
\text { judgment }\end{array}$ & Is about the action-state of values. & $\begin{array}{l}\text { Is about the instrumental and abstract state of } \\
\text { values. }\end{array}$ \\
\hline Value-action gab & $\begin{array}{l}\text { Is considered and addressed, because the action- } \\
\text { state of values is considered. }\end{array}$ & $\begin{array}{l}\text { Is not considered and addressed, because the } \\
\text { instrumental state of values (abstract concept) is } \\
\text { considered. }\end{array}$ \\
\hline $\begin{array}{l}\text { Individual } \\
\text { variations }\end{array}$ & $\begin{array}{l}\text { Is considered for its important as a source of } \\
\text { statistical variations within population. }\end{array}$ & Is not considered and cannot be measured. \\
\hline Per respondent & $\begin{array}{l}\text { Is possible, which can provide room for further } \\
\text { several statistical analysis such as MANOVA, for } \\
\text { variability within individuals. }\end{array}$ & $\begin{array}{l}\text { Is not possible, and this limit further statistical } \\
\text { analysis such as MANOVA, for variability within } \\
\text { individuals. }\end{array}$ \\
\hline \multirow[t]{2}{*}{$\begin{array}{l}\text { Data collection } \\
\text { methods }\end{array}$} & $\begin{array}{l}\text { Can be by three methods: questionnaire, } \\
\text { experimental observation and interview. Thus } \\
\text { method can support experimental design. }\end{array}$ & $\begin{array}{l}\text { Is only by questionnaire method. Thus cannot } \\
\text { support experimentation and interview approaches. }\end{array}$ \\
\hline & $\begin{array}{l}\text { Any data type is welcomed provided it is coupled } \\
\text { by an event's frequency factor. }\end{array}$ & Mainly rating scale data is welcomed. \\
\hline $\begin{array}{l}\text { Data organization } \\
\text { and scaling }\end{array}$ & May involve single or multiple approaches. & Not required. \\
\hline $\begin{array}{l}\text { Reliability of the } \\
\text { expected data }\end{array}$ & $\begin{array}{l}\text { Is more reliable, because the response is the } \\
\text { actual practice of the respondents not their } \\
\text { imagination or representation about values. }\end{array}$ & $\begin{array}{l}\text { Is less reliable, because the response may be an } \\
\text { imagination or representation respondents about } \\
\text { values. }\end{array}$ \\
\hline $\begin{array}{l}\text { Simplicity and time } \\
\text { efficiency }\end{array}$ & $\begin{array}{l}\text { Requires less time to respond to the questions, } \\
\text { because the response may have developed some } \\
\text { behavioral reflex. }\end{array}$ & $\begin{array}{l}\text { Requires more time to respond to the questions, } \\
\text { because the questions and its rating requires } \\
\text { reasoning. }\end{array}$ \\
\hline $\begin{array}{l}\text { Methodological } \\
\text { broadness }\end{array}$ & $\begin{array}{l}\text { Is broad in scope and applications. For instance, } \\
\text { values for material object is considered, this can } \\
\text { permit other field of studies such as ethnobotany } \\
\text { to apply. }\end{array}$ & $\begin{array}{l}\text { Other aspects of studies are ignored, because } \\
\text { material values for particular object are not } \\
\text { considered within the scope. }\end{array}$ \\
\hline $\begin{array}{l}\text { Theoretical } \\
\text { considerations }\end{array}$ & $\begin{array}{l}\text { The variables and their interactions reflect the } \\
\text { theoretical conceptions about values. See** }\end{array}$ & $\begin{array}{l}\text { The method did not address some theoretical } \\
\text { issues such as. See** }\end{array}$ \\
\hline
\end{tabular}

\footnotetext{
*Ambiguous in sense that the method may fail to provide consistent and valid result. For instance, if scale points 2,1 and -1 are the only responded points in SVS method by 20,50, and 90 respondents respectively, the mean score would be equal to zero, that means no values score at all, while it is invalid to accept.

**(1) Value-action gab (Fishbein and Ajzen 1975), (2) Repeated habituations and engagement in value-actions as a strengthening factor of values (Flouri 1999; Sheldon 2000; Goldberg 2003; Hüther 2006; Banerjee 2008; and Holmes 2011), (3) Actions as driven forces and end-state of values (Holmes 2012; Schwartz 2006, 2012), (4) Value dynamics: that values changes in all our day-to-day lives (Holmes 2012)
} 
OPTIMIZATION OF VALUE MEASUREMENT METHODS

Table 8: Comparisons between KVS and other ethnobotanical value methods

\begin{tabular}{|c|c|c|c|c|c|c|c|c|}
\hline \multirow[b]{2}{*}{ Criteria considered } & \multirow{2}{*}{$\begin{array}{c}\text { KVS } \\
\text { Action- } \\
\text { value } \\
\text { index } \\
\end{array}$} & \multirow{2}{*}{$\begin{array}{c}\begin{array}{c}\text { Prance } \text { et } \\
\text { al. 1987) }\end{array} \\
\text { Use } \\
\text { Value }\end{array}$} & \multicolumn{4}{|c|}{ (Phillips and Gentry 1993a) } & \multirow{2}{*}{$\begin{array}{c}\begin{array}{c}\text { Kremen } \text { et } \\
\text { al.1998) }\end{array} \\
\begin{array}{c}\text { Choice } \\
\text { Value }\end{array}\end{array}$} & \multirow{2}{*}{$\begin{array}{c}\begin{array}{c}\text { Byg \& Balslev } \\
\text { 2001) }\end{array} \\
\begin{array}{c}\text { Importance } \\
\text { Value }\end{array}\end{array}$} \\
\hline & & & $\begin{array}{c}\text { Species Use-Value } \\
\text { (For one } \\
\text { informant) } \\
\end{array}$ & $\begin{array}{c}\text { Species Use-Value } \\
\text { (For one species } \\
\text { across all informants) }\end{array}$ & $\begin{array}{l}\text { Family Use } \\
\text { Value }\end{array}$ & $\begin{array}{l}\text { Relative Use } \\
\text { Value }\end{array}$ & & \\
\hline $\begin{array}{l}\text { Consideration for other value } \\
\text { aspects* }\end{array}$ & YES & $\mathrm{NO}$ & NO & NO & NO & NO & NO & $\mathrm{NO}$ \\
\hline $\begin{array}{l}\text { Frequency of action/activity/uses } \\
\text { considered }\end{array}$ & YES & NO & NO & NO & NO & NO & NO & NO \\
\hline $\begin{array}{l}\text { Distinction between current and } \\
\text { historical use }\end{array}$ & YES & NO & NO & NO & NO & NO & NO & NO \\
\hline $\begin{array}{l}\text { Result theoretically meaningful } \\
\text { about values }\end{array}$ & YES & NO & $\mathrm{NO}$ & NO & NO & NO & NO & NO \\
\hline Result ambiguity. See this case** & NO & YES & YES & YES & YES & YES & YES & YES \\
\hline
\end{tabular}

Table 8: Cont.....

\begin{tabular}{|c|c|c|c|c|c|c|c|c|c|c|}
\hline \multirow[b]{2}{*}{ Criteria considered } & \multirow[b]{2}{*}{ KVS } & \multicolumn{5}{|c|}{ (Gomez-Beloz 2003) } & \multicolumn{4}{|c|}{ (Reyes-Garcia et al. 2006) } \\
\hline & & $\begin{array}{c}\text { Reported } \\
\text { Use } \\
\text { Value } \\
\end{array}$ & $\begin{array}{r}\text { Reported } \\
\text { Use Value } \\
\text { (Per Plant) } \\
\end{array}$ & $\begin{array}{c}\text { Plant Part } \\
\text { Used }\end{array}$ & $\begin{array}{c}\text { Intra-specific } \\
\text { Use Value }\end{array}$ & $\begin{array}{c}\text { Overal } \\
\text { Use }\end{array}$ & $\begin{array}{c}\text { Cultural } \\
\text { Value } \\
\text { Index } \\
\end{array}$ & $\begin{array}{c}\text { Practical } \\
\text { Value Index }\end{array}$ & $\begin{array}{l}\text { Economic } \\
\text { Value } \\
\text { Index } \\
\end{array}$ & $\begin{array}{l}\text { Total Value } \\
\text { Index }\end{array}$ \\
\hline $\begin{array}{l}\text { Consideration for other } \\
\text { value aspects* }\end{array}$ & YES & $\mathrm{NO}$ & $\mathrm{NO}$ & $\mathrm{NO}$ & $\mathrm{NO}$ & $\mathrm{NO}$ & NO & $\mathrm{NO}$ & NO & NO \\
\hline $\begin{array}{l}\text { Frequency of } \\
\text { action/activity/uses } \\
\text { considered }\end{array}$ & YES & NO & NO & NO & NO & $\mathrm{NO}$ & $\mathrm{NO}$ & YES & YES & YES \\
\hline $\begin{array}{l}\text { Distinction between } \\
\text { current and historical use }\end{array}$ & YES & NO & NO & NO & NO & $\mathrm{NO}$ & $\mathrm{NO}$ & NO & $\mathrm{NO}$ & NO \\
\hline $\begin{array}{l}\text { Result theoretically } \\
\text { meaningful about values }\end{array}$ & YES & $\mathrm{NO}$ & $\mathrm{NO}$ & $\mathrm{NO}$ & NO & $\mathrm{NO}$ & $\mathrm{NO}$ & $\mathrm{NO}$ & $\mathrm{NO}$ & NO \\
\hline $\begin{array}{l}\text { Result ambiguity. See this } \\
\text { case** }\end{array}$ & NO & YES & YES & YES & YES & YES & YES & $\mathrm{NO}$ & $\mathrm{NO}$ & $\mathrm{NO}$ \\
\hline
\end{tabular}

\footnotetext{
*Such as exploitation value, processing value, regeneration value, market value, and other material values related to natural plant biodiversity.

**A species with the highest frequency of citations or use categories is considered most significant even if it is less frequently utilized over the others, or the use is historical not current.
} 
OPTIMIZATION OF VALUE MEASUREMENT METHODS

\section{Simulation Analysis}

In this subsection, a simulated comparison between KVS and SVS method is presented by example 1, and example 2 is provided to show how multiple frequency factors can be solved into a one logical and meaningful result.

\section{Example 1:}

Suppose we establish a mutual correspondence between KVS and SVS as shown in table 9. If table 10 is a sample of observations or respondents' responses from a study comprised a population sample of 1,500 individuals from a random sampling. We were then asked to calculate the value priorities of that particular value items A-1 to A-4. Following the two methods in comparison, the result shows that 0.20 and 1.40 are the average value priority score of value A from KVS and SVS respectively. From logical and theoretical points of views, we can reject that the result of item A-2 cannot be zero.

When we think of how psychologically meaningful the results from KVS is, we can say that for every one hundred randomly selected individuals in the population, there is a mean importance for that value A by practice almost every year (reference by $1 / 5=0.20$ ), and this signifies that there is low values (taken a reference from table 6) for that value type $A$ in the population. This result and its interpretation make sense psychologically. In other hand, we can only say that the result from SVS, the value type A is either recognized important or unlabelled, it only shows a value, but what sense out of it ?, we cannot explain.

Table 9: Establishing correspondence between KVS and SVS response scales

\begin{tabular}{|c|c|c|c|c|c|c|}
\hline \multicolumn{7}{|c|}{ Kab's Value Survey } \\
\hline Every day \& night & Every day/night & Every week & Every month & Every year & Nc & Nc \\
\hline 5 & 4 & 3 & 2 & 1 & $*$ & $*$ \\
\hline \multicolumn{7}{|c|}{ Assume a mutual correspondence between } \\
\hline 7
\end{tabular}

$* \mathrm{Nc}=$ Not considered in the scale. 
OPTIMIZATION OF VALUE MEASUREMENT METHODS

Table 10: Result comparison from KVS and SVS methods

\begin{tabular}{|c|c|c|c|c|c|c|c|c|c|c|}
\hline & \multicolumn{7}{|c|}{ Rating/Ranking scale } & & & \\
\hline SVS & 7 & 6 & 4.5 & 3 & 2.5 & $\mathbf{0}$ & -1 & & & \\
\hline KVS & 5 & 4 & 3 & 2 & 1 & $\mathrm{Nc}$ & $\mathrm{Nc}$ & & & \\
\hline $\begin{array}{c}\text { Value type/ } \\
\text { Items }\end{array}$ & \multirow{2}{*}{\multicolumn{7}{|c|}{ Number of respondents that responded (na) }} & & \multicolumn{2}{|c|}{$\begin{array}{c}\text { Value Priority } \\
\text { Scores }\end{array}$} \\
\hline & & & & & & & & $\mathbf{N p}$ & KVS & SVS \\
\hline A-1 & 55 & 200 & 0 & 400 & 0 & 200 & 645 & 1500 & 0.25 & 1.43 \\
\hline A-2 & 0 & 0 & 0 & 0 & 100 & 1150 & 250 & 1500 & 0.01 & 0 \\
\hline A-3 & 30 & 70 & 80 & 250 & 200 & 620 & 250 & 1500 & 0.18 & 1.33 \\
\hline A-4 & 100 & 200 & 300 & 200 & 200 & 400 & 100 & 1500 & 0.37 & 2.83 \\
\hline & & Av & & & & & & & 0.20 & 1.40 \\
\hline
\end{tabular}

$\mathrm{Np}=$ Population sample; $\mathrm{na}=$ number of respondents for each items; $\mathrm{Nc}=$ Not considered;

KVS = Kab’s Value Survey; SVS = Schwartz's Value Survey.

\section{Example 2:}

Suppose a table 11 is a sample of observations or respondents' responses from a study comprised a population sample of 600 individuals from a random sampling. We were then asked to calculate the value priorities of that set of values A to G. Results in table 11 show that all the values A-G are worthy important for the survival of that population. A visible variation in value priorities from one value to the others take sequence as:

$$
\mathrm{C} \rightarrow \mathrm{A} \rightarrow \mathrm{G} \rightarrow \mathrm{B} \rightarrow \mathrm{F} \rightarrow \mathrm{D} \rightarrow \mathrm{E}
$$

This signifies that value $\mathrm{C}$ has the highest value and extremely important in the population with E the least, but highly significance. If, for instance, by making this piece of discussion about the result, a meaningful comparisons and conclusion can be made. In this case, by considering more variables in data collection and data analysis could minimize errors due to respondents' biasness and maximize precisions and result validity. 
OPTIMIZATION OF VALUE MEASUREMENT METHODS

Table 11: Solving a sample problem using from KVS method

\begin{tabular}{|c|c|c|c|c|c|c|c|c|c|c|c|c|c|c|c|c|}
\hline & \multicolumn{15}{|c|}{ Kab's Value Survey (KVS) } & \\
\hline & \multicolumn{3}{|c|}{5 (Every D \& N) } & \multicolumn{3}{|c|}{4 (Every DL or DN) } & \multicolumn{3}{|c|}{3 (Every W) } & \multicolumn{3}{|c|}{2 (Every M) } & \multicolumn{3}{|c|}{1 (Every Y) } & \\
\hline & $\begin{array}{c}3-4 \\
\text { times }\end{array}$ & $\begin{array}{c}2-3 \\
\text { time }\end{array}$ & $\begin{array}{c}1-2 \\
\text { times }\end{array}$ & $\begin{array}{c}3-4 \\
\text { times }\end{array}$ & $\begin{array}{c}2-3 \\
\text { time }\end{array}$ & $\begin{array}{c}1-2 \\
\text { times }\end{array}$ & $\begin{array}{c}3-4 \\
\text { times }\end{array}$ & $\begin{array}{c}2-3 \\
\text { time }\end{array}$ & $\begin{array}{c}1-2 \\
\text { times }\end{array}$ & $\begin{array}{c}3-4 \\
\text { times }\end{array}$ & $\begin{array}{c}2-3 \\
\text { time }\end{array}$ & $\begin{array}{c}1-2 \\
\text { times }\end{array}$ & $\begin{array}{c}3-4 \\
\text { times }\end{array}$ & $\begin{array}{c}2-3 \\
\text { time }\end{array}$ & $\begin{array}{c}1-2 \\
\text { times }\end{array}$ & \\
\hline RERN & 4.9 & 4.6 & 4.3 & 3.9 & 3.6 & 3.3 & 2.9 & 2.6 & 2.3 & 1.9 & 1.6 & 1.3 & 0.9 & 0.6 & 0.3 & \\
\hline $\begin{array}{l}\text { Value/ } \\
\text { Action }\end{array}$ & \multicolumn{15}{|c|}{ Number of respondents that responded (na) } & $\begin{array}{l}\mathbf{A V I} / \\
\text { VPS }\end{array}$ \\
\hline $\mathrm{A}$ & 121 & 99 & 108 & 65 & 45 & 23 & 10 & 9 & 12 & 5 & 1 & 5 & 0 & 0 & 0 & 0.70 \\
\hline $\mathrm{B}$ & 87 & 65 & 0 & 23 & 22 & 45 & 67 & 66 & 13 & 12 & 22 & 12 & 9 & 9 & 0 & 0.51 \\
\hline $\mathrm{C}$ & 150 & 101 & 106 & 56 & 76 & 55 & 9 & 8 & 9 & 5 & 9 & 6 & 0 & 0 & 0 & 0.81 \\
\hline $\mathrm{D}$ & 12 & 65 & 34 & 22 & 45 & 12 & 66 & 23 & 66 & 12 & 0 & 12 & 6 & 21 & 9 & 0.42 \\
\hline$E$ & 0 & 6 & 3 & 23 & 22 & 11 & 34 & 44 & 33 & 6 & 2 & 9 & 0 & 6 & 5 & 0.19 \\
\hline $\bar{F}$ & 13 & 31 & 23 & 56 & 21 & 45 & 65 & 31 & 35 & 84 & 54 & 77 & 8 & 3 & 5 & 0.48 \\
\hline $\mathrm{G}$ & 91 & 55 & 62 & 45 & 56 & 12 & 34 & 45 & 35 & 34 & 8 & 10 & 1 & 8 & 9 & 0.59 \\
\hline
\end{tabular}

RERN = Resultant Event's rank number; $\mathrm{D}=$ Day; $\mathrm{N}$ = Night; $\mathrm{DL}=$ Daylight; DN = Day-night; $\mathrm{W}=$ Week; $\mathrm{M}=$ Month; $\mathrm{Y}=$ Year; $\mathrm{Np}=600=$ Population sample; na = number of respondents for each items; $\mathrm{AVI}=$ Action-value Index; VPS = Values priority score.

\section{Conclusion}

Based on the results of methodological and simulation comparisons, it can be concluded that Kab's Value Survey (KVS) for its considerations to the theoretical explanations distinguishes itself over other methods of value measurement in the sense that the methodology employed is more broad in its scope and applications; more simple, and specific in terms of response scale, instruments for data collection, data analysis, and of course data presentation; more meaningful in terms of result interpretations; more reliable in terms of data and result precisions (because of multiple frequency factors and the response scale considered); more statistically sound (because result is interpreted as probability). The method however solved the criticized limitations that exist in the well known and adopted methods of values measurement from psychological and ethnobotanical perspectives. Interested researchers in psychology, sociology, ethnobotany, ethnozoology, history, economics and other social science would find this methodology helpful for their field and experimental research design. 
OPTIMIZATION OF VALUE MEASUREMENT METHODS

\section{Reference}

Banerjee, R. and Dittmar, H. (2008). Individual differences in children's materialism: the role of peer relations. Personality and Social Psychology Bulletin, 31(1), 17-31.

Begossi, A., Hanazaki, N., Tamashiro, J. Y. (2002). Medicinal plants in the Atlantic Forest Brasil: Knowledge, use and conservation. Human Ecology, 303, 281-299.

Bilsky, W., Janik, M., \& Schwartz, S. H. (2011). The structural organization of human values: Evidence from three rounds of the European Social Survey (ESS). Journal of CrossCultural Psychology, 42(5), 759-776. doi: 10.1177/0022022110362757.

Byg, A., \& Balslev, H. (2001). Diversity and use of palms in Zahamena, eastern Madagascar. Biodiversity and Conservation, 10, 951-970.

Camou-Guerrero, A., Reyes-Garcia, V., Martinez-Ramos, M., Casas, A. (2008). Knowledge and use value of plant species in a Raramuri community: A gender perspective for conservation. Human Ecology, 36, 259-272.

Case, R. J., Pauli, G. F., Soejarto, D. D. (2005). Factors in main-taining indigenous knowledge among ethnic com-munities of Manus Island. Eco Bot, 594, 356-365.

Collins, P. R., Lee, J. A., Sneddon, J. N., \& Döring, A. K. (2017). Examining the consistency and coherence of values in young children using a new Animated Values Instrument. Personality and Individual Differences, 104, 279-285.

Davidov, E., Schmidt, P., \& Schwartz, S. H. (2008). Bringing values back in the adequacy of the European Social Survey to measure values in 20 countries. Public Opinion Quarterly, $72(3), 420-445$.

Fishbein, M., Ajzen, I. (1975). Belief, attitude, intention, and behavior: An introduction to theory and research. Reading: MA: Addison-Wesley. 
OPTIMIZATION OF VALUE MEASUREMENT METHODS

Flouri, E. (1999). An integrated model of consumer materialism: can economic socialisation and maternal values predict materialistic attitudes in adolescents? Journal of SocioEconomics, 28 (6), 707-724.

Frei, B., Baltisberger, M., Sticher, O., Heinrich, M. (1998). Medical ethno-medicine of the Zapotecs of the Isthmus-Sierra Oaxaca, Mexico: Documentation and assessment of indigenous uses. J Ethnophar-macol, 62, 149-165.

Goldberg, M. E., Gorn, G. J., Peracchio, L. A. and Bamossy, G. (2003). Understanding materialism among youth. Journal of Consumer Psychology, 13(3), 278-288

Gómez-Beloz, A. (2002). Plant use knowledge of the Winiki-na Warao: The case for questionnaires in ethnobotany. Economic Botany, 56, 231-241.

Hoffman, B., Gallaher, G. (2007). Importance indices in ethno-medicine. Ethno-medicine Research and Application. 5, 201-218.

Holmes, T., Blackmore, E., Hawkins, R., and Wakeford, T. (2011). The Common Cause Handbook, Public Interest Research Centre Publishers, United Kingdom, pp. 30. ISBN: 978-0-9503648-7-2.

Hood, Jacqueline. (2003). The Relationship of Leadership Style and CEO Values to Ethical Practices in Organizations. Journal of Business Ethics, 43, 263-273.

Hüther, G. (2006). Neurobiological approaches to a better understanding of human nature and human values. The Journal for Transdisciplinary Research in Southern Africa, 2(2), 331343.

Kluckhohn, C. (1951). Values and value-orientations in the theory of action: An exploration in definition and classification. In T. Parsons \& E. Shils (Eds.), Toward a general theory of action (pp. 388-433). Cambridge. MA: Harvard University Press. 
OPTIMIZATION OF VALUE MEASUREMENT METHODS

Kremen, C., Raymond, I. \& Lance, K. (1998). An interdisciplinary tool for conservation impacts in Madagascar. Conservation Biology, 12, 549-563.

Lee, J. A., Soutar, G. N., Louviere, J. J. (2005). An Alternative Approach to Measuring Schwartz's Values: The Best-Worst Scaling Approach". Journal of Personality Assessment, 90, 335-347

Lindeman, M., Verkasalo, M. (2005). Measuring Values With the Short Schwartz's Value Survey". Journal of Personality Assessment, 85: 170-178.

Mathur, M., \& Sundaramoorthy, S. (2013). Census of Approaches Used in Quantitative Ethnobotany, Ethno Med, 7(1): 31-58.

Oishi, S., Schimmack, U., Diener, E., \& Suh, E. M. (1998). The measurement of values and individualism-collectivism. Personality and Social Psychology Bulletin, 24(11), 11771189.

Parks-Leduc, L., Feldman, G., and Bardi, A. (2015). Personality Traits and Personal Values: A Meta-Analysis. Personality and Social Psychology Review, 19(1), 3-29. doi: $10.1177 / 1088868314538548$.

Phillips, O., \& Gentry, A. H. (1993). The useful plants of Tambopata, Peru: I. Statistical hypotheses tests with a new quantitative technique. Economic Botany, 47, 15-32.

Prance, G.T., Balee, W., Boom, B. M., \& Carneiro, R. L., (1987). Quantitative ethnobotany and the case for conservation in Amazonia. Conservation Biology, 1, 296-310.

Reyes-García, V., Huanca, T., Vadez, V., \& Leonard, W. D. (2006). Cultural, practical, and economic value of wild plants: A quantitative study in the Bolivian Amazon. Economic Botany, 60, 62-74. 
OPTIMIZATION OF VALUE MEASUREMENT METHODS

Roccas, S., Sagiv, L., \& Navon, M. (2017). Methodological Issues in Studying Personal Values. Values and Behavior, 15-50. doi:10.1007/978-3-319-56352-7_2.

Rokeach, M. (1973). The nature of human values. New York: Free press.

Rudnev, M. (2011). Constraints and opportunities of 10 Schwatz Value Survey items in World Values Survey. ESRA Conference, 20 July, 2011. Lausanne, Switzerland.

Sandy, C. J., Gosling, S. D., Schwartz, S. H., \& Koelkebeck, T. (2016). The development and validation of brief and ultrabrief measures of values. Journal of Personality Assessment, $1-11$.

Schwartz, S. H. (1992). Universals in the content and structure of values: Theoretical advances and empirical tests in 20 countries. Advances in Experimental Social Psychology, 25(1), $1-65$.

Schwartz, S. H. (2005). Robustness and fruitfulness of a theory of universals in individual human values. In A. Tamayo \& J. B. Porto (Eds.), Valores ecomportamentonasorganizaçAtoes [Values and behavior in organizations] (pp. 56-95). Petrópolis: Vozes.

Schwartz, S. H. (2006). Les valeurs de base de la personne: Theorie, mesures et applications [Basic human values: Theory, measurement, and applications]. Revue Fran_caise de Sociologie, 47, 249-288.

Schwartz, S. H. (2012). An overview of the Schwartz theory of basic values. Online Reading in Psychology and Culture, 2(1), Article no. 11.

Sekerdej, M., \& Roccas, S. (2016). Love versus loving criticism: Disentangling conventional and constructive patriotism. British Journal of Social Psychology, 55(3), 499-521.

Sheldon, K. M., \& McGregor, H. (2000). Extrinsic value orientation and the tragedy of the commons. Journal of Personality, 68 (2), 383-411 
OPTIMIZATION OF VALUE MEASUREMENT METHODS

Thomas, E., Vandbrock, I., Sancae, S., Damme, P. V. (2009). Cultural significance of medicinal plant families and species among Quechuafurmurs in Apilapam-pa, Bolivia. $J$ of Ethnopharmacol, 22: 60-67.

Voeks, R. A., Leony, A. (2004). Forgetting the forest: As-sessing medicinal plant erosion in eastern Brazil. Econ Bot, 58, 284-306.

Acknowledgements: I thank for the motivations and encouragement received from Abubakar Bello of Umaru Musa Yar'adua University Katsina. This research did not receive any specific grant from funding agencies in the public, commercial, or not-for-profit sectors.

Conflicts of Interest: The author declares no conflict of interest.

Correspondence: Correspondence should be address to Kabir Abdullahi Bindawa, Department of Biology, Faculty of Natural and Applied Sciences, Umaru Musa Yar'adua University, P.M.B., 2218 Katsina, Katsina State, Nigeria. 